\title{
Management of late onset urea cycle disorders - a remaining challenge for the intensivist?
}

\author{
S. Redant ${ }^{1}$, A. Empain², A. Mugisha' ${ }^{1}$ P. Kamgang ${ }^{3}$, R. Attou' ${ }^{1}$, P. M. Honoré ${ }^{*}$ and D. De Bels ${ }^{1}$
}

\begin{abstract}
Background: Hyperammonemia caused by a disorder of the urea cycle is a rare cause of metabolic encephalopathy that may be underdiagnosed by the adult intensivists because of its rarity. Urea cycle disorders are autosomal recessive diseases except for ornithine transcarbamylase deficiency (OTCD) that is X-linked. Optimal treatment is crucial to improve prognosis.

Main body

We systematically reviewed cases reported in the literature on hyperammonemia in adulthood. We used the US National Library of Medicine Pubmed search engine since 2009. The two main causes are ornithine transcarbamylase deficiency followed by type II citrullinemia. Diagnosis by the intensivist remains very challenging therefore delaying treatment and putting patients at risk of fatal cerebral edema. Treatment consists in adapted nutrition, scavenging agents and dialysis. As adults are more susceptible to hyperammonemia, emergent hemodialysis is mandatory before referral to a reference center if ammonia levels are above $200 \mu \mathrm{mol} / \mathrm{l}$ as the risk of cerebral edema is then above 55\%. Definitive therapy in urea cycle abnormalities is liver transplantation.

Conclusion: Awareness of urea cycle disorders in adults intensive care units can optimize early management and accordingly dramatically improve prognosis. By preventing hyperammonemia to induce brain edema and herniation leading to death.
\end{abstract}

Keywords: Urea cycle disorders, Hyperammonemia, Dialysis, Scavenging therapy

\section{Background}

Hyperammonemia caused by a disorder of the urea cycle is a rare cause of metabolic encephalopathy that may be underdiagnosed by the adult intensivists because of its rarity. An acute ammonia elevation, if left untreated, leads to brain swelling, structural damage and death [1]. Ammonia diffuses freely across the blood-brain barrier and is converted with alanine to glutamine by glutamine synthase. Glutamine is the main intracellular osmole of

\footnotetext{
*Correspondence: patrick.honore@chu-brugmann.be

1 Department of Intensive Care, Université Libre de Bruxelles (ULB), CHU Brugmann-Brugmann University Hospital, 4, Place Arthur Van Gehuchten, 1020 Brussels, Belgium

Full list of author information is available at the end of the article
}

the brain. Its accumulation causes the swelling of astrocytes during hyperammonemia (Alzheimer type II astrocyte) [2].

Urea cycle disorders (UCD, Fig. 1) are autosomal recessive diseases except for ornithine transcarbamylase deficiency (OTCD) that is X-linked [3]. The annual incidence in the United States is 1: 35,000 births which represents 113 new cases per year [4]. The UCDs comprise 8 abnormalities listed in Table 1 altering cofactors, enzymes or transporters [3]. The usual presentation of urea cycles disorders is neonates with extremely high levels of ammonia and coma. This model constitutes the majority of the reported cases in the literature. However, some cases are reported with onset in adulthood. A partial or moderate deficiency in a urea
Springer Open

(c) The Author(s) 2021. This article is licensed under a Creative Commons Attribution 4.0 International License, which permits use, sharing, adaptation, distribution and reproduction in any medium or format, as long as you give appropriate credit to the original author(s) and the source, provide a link to the Creative Commons licence, and indicate if changes were made. The images or other third party material in this article are included in the article's Creative Commons licence, unless indicated otherwise in a credit line to the material. If material is not included in the article's Creative Commons licence and your intended use is not permitted by statutory regulation or exceeds the permitted use, you will need to obtain permission directly from the copyright holder. To view a copy of this licence, visit http://creativeco mmons.org/licenses/by/4.0/. 


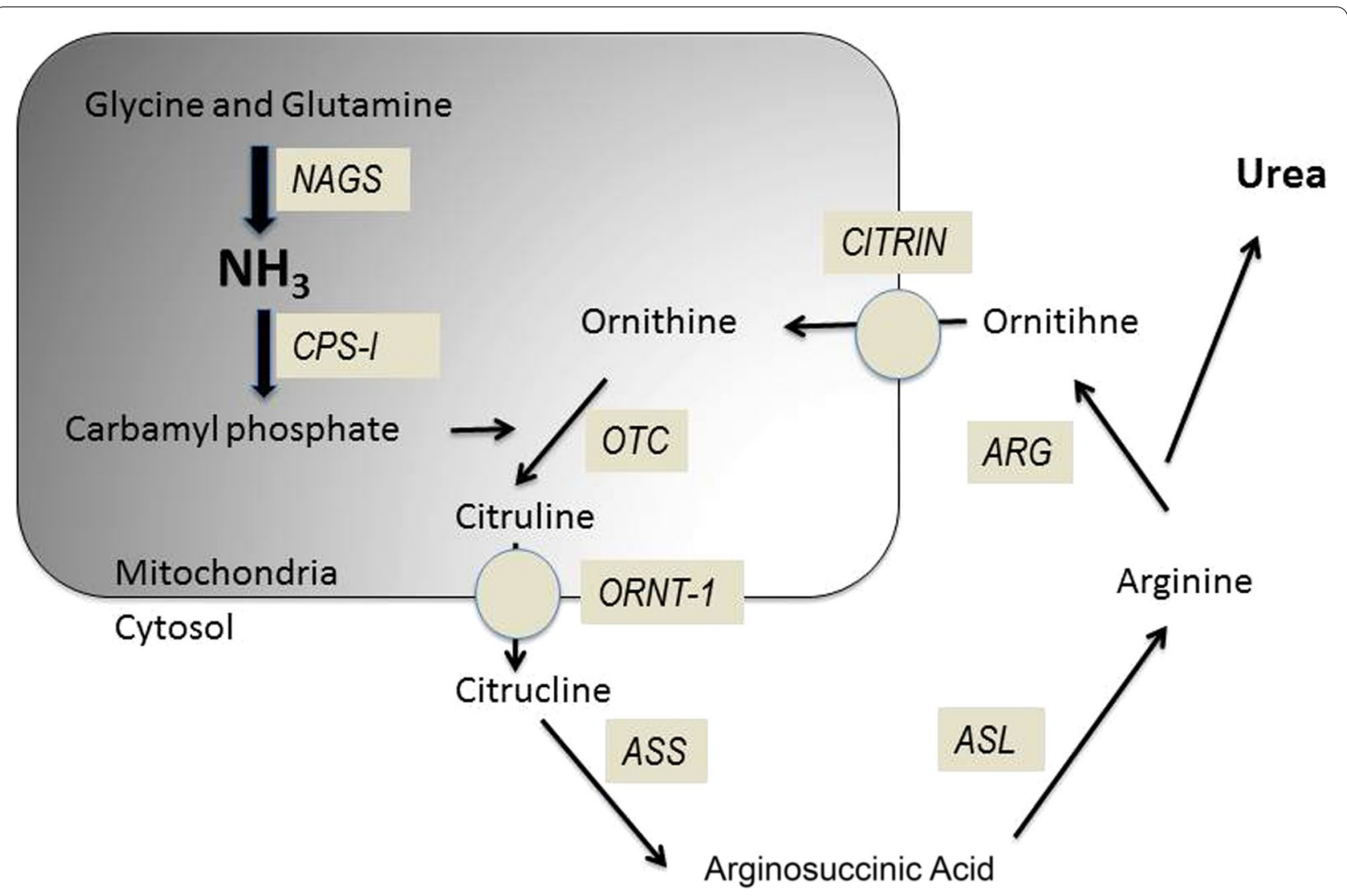

Fig. 1 Urea cycle disorders: NAGS: N-acetyl glutamate synthetase, CPS1: Carbamyl phosphate synthetase 1, OTC: Ornithine transcarbamylase, ORNT1 mitochondrial ornithine transporter 1, CITRIN: Citrullinemia type II (mitochondrial aspartate/glutamate) carrier, ASS: Arginosuccinic acid synthetase 1, ASL: Arginosuccinic acid lyase

Table 1 The various deficiencies of urea cycle disorders adapted from Waisbren [3]

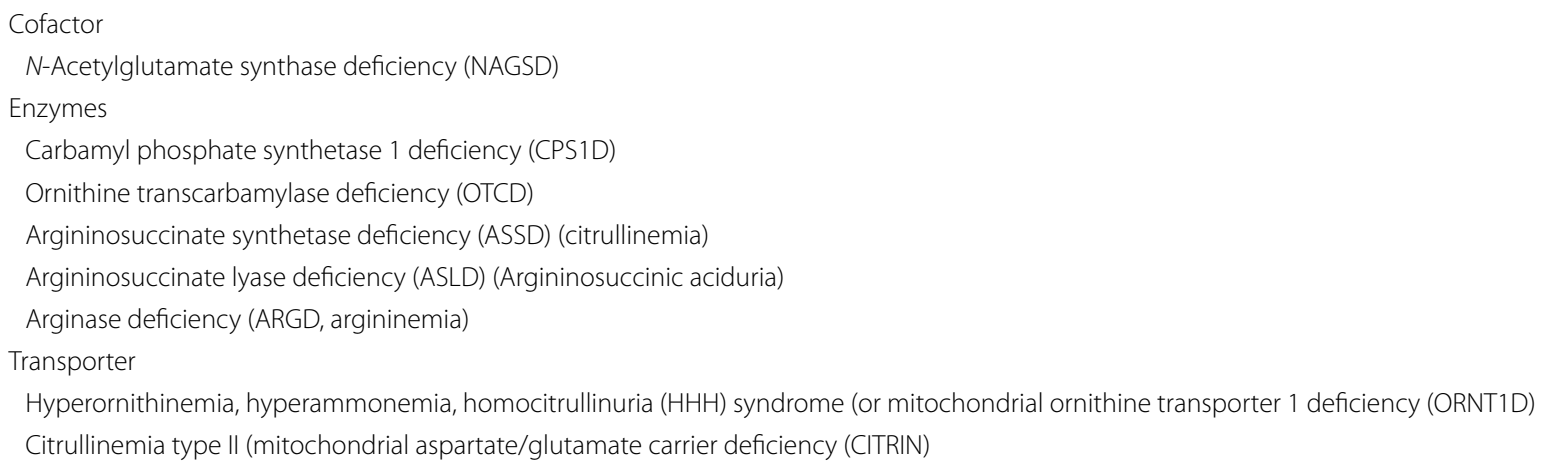

cycle enzyme allows patients to evolve without incident until adulthood [5]. These patients avoid proteins in their diet, some to the point of becoming vegetarian. The onset of symptoms coincides with a precipitating factor such as excess protein intake, infection, trauma, surgery, deliverance [6] or medications as valproate or glucocorticoids [7]. The authors reviewed systematically the clinical cases in the literature in order to obtain information on presentation and management of patients with an UCD in adulthood. We wish to focus 
our review on the different therapeutic possibilities with which the intensivist must be familiar.

\section{Main text Pathophysiology}

During metabolic stress induced by infection, childbirth or surgery, a catabolic phase leads to the metabolism of a large amount of proteins. This excess intake will exceed the capacity of the urea cycle, especially if it has an enzymatic deficit. A significant production of ammonia then follows. Ammonia passes into the circulation and crosses the blood-brain barrier. The ammonia will exert a direct toxic effect on the neurotransmission responsible for part of the neurological symptomatology. In addition, the astrocytic glutamine synthetase will convert ammonia and glutamate into glutamine, which in turn acts as an osmolyte and will increase cerebral volume [8]. Intra cranial hypertension appears inducing coma, cerebral engagement and death of the patient.

A particular form is the form induced by Valproate. Valproate causes hyperammonemia by blocking carbamoyl phosphate synthetase, which is an enzyme at the beginning of the urea cycle (Fig. 1). The second mechanism is the inhibition of carnitine transport in the mitochondria, which causes a shift toward protein degradation responsible for hyperammonemia [14]. In the case of an urea cycle disorder, the blocking of carbamoyl synthetase and the increase of protein degradation favor or exacerbate the development of a hyperammonemic crisis.

\section{Literature}

We conducted a systematic review of the case-reports described in the literature $[1,6,7,9-34]$. We used the US National Library of Medicine Pubmed search engine with the following key words: "adult-onset", "Late-onset", and "urea cycle disorder", "inborn urea metabolism disorder". We deliberately excluded cases-series publications, reviews, fundamental research articles and the case reports where the final diagnosis was not confirmed (Fig. 2).

We found 40 adult case-reports meeting our selection criteria (Table 2). The average ammonia level measured at admission is $280(162-480) \mu \mathrm{mol} / \mathrm{l}$ with a mean peak of $300(228-541) \mu \mathrm{mol} / \mathrm{l}$. Symptoms are listed in Table 3, the most common being confusion. Cerebral edema was highlighted in only 13 cases. The most frequently found favoring factors were infection and type of nutrition. Other factors are listed in Table 4. Eight patients spontaneously adopted protein-free diets before diagnosis was made. Nineteen patients were treated with benzoate, 2 with phenylbutyrate and 8 with the combination of both. Fifteen patients received l-arginine, 1 patient received l-carnitine and 6 received the combination of both.

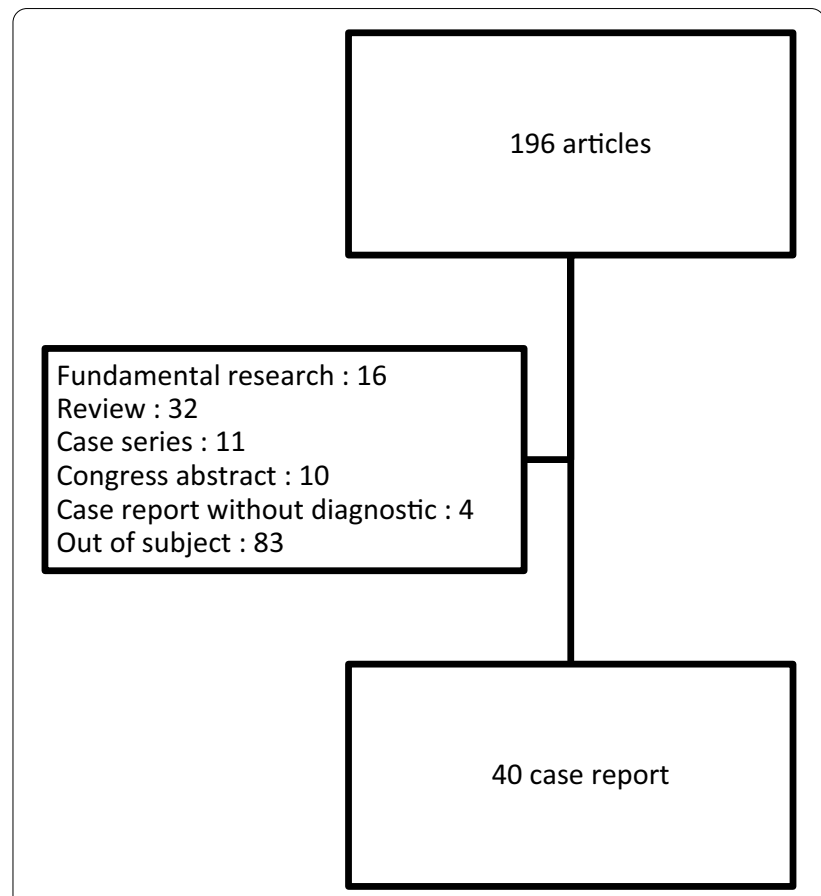

Fig. 2 Literature flow chart of analyzed case reports

Four patients received citrulline. Dialysis was used in 14 patients and hypothermia in only one patient (Table 5). The most frequently found anomaly was ornithine transcarbamylase (OTC) deficiency with the same male / female ratio followed by citrullinemia type II (Fig. 3). Height patients died. Ninety-four publications concerned other metabolic errors than the urea cycle.

\section{Diagnosis}

The diagnosis is made difficult by the non-specific nature of symptoms. In 42 percent of cases, patients do not receive a scavenging treatment. Twelve patients received neither arginine nor L-carnitine. In 5 cases, the situation was considered out of date, which led to a lack of treatment. The time to initiate treatment was not specified. Despite high levels of ammonia (27 patients above $250 \mu \mathrm{mol} / \mathrm{l}$ ), dialysis was only offered in 14 patients. In the height patients who died, only 4 were dialyzed. Bernal et al. showed that an ammonia level $>100 \mu \mathrm{mol} / \mathrm{ml}$ predicted the occurrence of severe encephalopathy with $70 \%$ accuracy. They also observed that $55 \%$ of patients with ammonia levels $>200 \mu \mathrm{mol} / \mathrm{l}$ had Intracranial hypertension [35]. In hyperammonemia associated with urea cycle disorders, treatment with hemodialysis can reverse encephalopathy and prevent brain edema and death [36]. The diagnosis of abnormalities of the urea cycle requires a determination of organic and urinary amino acids, acylcarnitines and follows an algorithm shown in Fig. 4 [37]. 
Table 2 Adult case-reports of late onset urea cycle disorders

\begin{tabular}{|c|c|c|c|c|c|c|c|c|c|c|}
\hline $\mathrm{N}^{\circ}$ & Ref & Sex & Age & Acute symptoms & $\begin{array}{l}\text { Maximal } \\
\text { ammonia }\end{array}$ & Brain edema & Defective enzyme & Acute treatment & Dialysis & Outcome \\
\hline 1 & {$[34]$} & M & 48 & Coma, headache, S, N, V & 497 & Yes & ORNT1 & B & Yes & $\mathrm{F}$ \\
\hline 2 & [33] & $\mathrm{F}$ & 19 & $\mathrm{~N}, \mathrm{~V}$ & ND & Yes & OTC & Other & No & $\mathrm{D}$ \\
\hline 3 & {$[32]$} & $\mathrm{F}$ & 52 & BA, headache, S, N, V & 330 & No & NAGS & B & No & $\mathrm{F}$ \\
\hline 4 & {$[31]$} & M & 69 & $\mathrm{~N}, \mathrm{~V}$ & 293 & No & OTC & Other & Yes & $\mathrm{F}$ \\
\hline 5 & {$[30]$} & M & 66 & Coma, BA, S & 494 & Yes & OTC & Other & Yes & $\mathrm{F}$ \\
\hline 6 & {$[29]$} & M & 60 & Coma & 158 & Yes & ARG & B & No & $\mathrm{F}$ \\
\hline 7 & {$[7]$} & M & 67 & S & ND & Yes & OTC & Other & No & $F$ \\
\hline 8 & {$[28]$} & $\mathrm{F}$ & 52 & Coma & 684 & No & OTC & Other & No & $\mathrm{F}$ \\
\hline 9 & [1] & $\mathrm{F}$ & 39 & Coma, N, V & 288 & No & OTC & B & Yes & $\mathrm{F}$ \\
\hline 10 & {$[27]$} & K & 62 & Behavior, S & 154 & No & CITRIN & Other & No & $\mathrm{F}$ \\
\hline 11 & {$[26]$} & $\mathrm{F}$ & 73 & Coma, Behavior & 147 & No & CITRIN & Other & Yes & $\mathrm{F}$ \\
\hline 12 & {$[6]$} & $\mathrm{F}$ & 59 & Coma & 280 & No & NAGS & B & No & $\mathrm{F}$ \\
\hline 13 & {$[25]$} & M & 31 & BA & 598 & No & CITRIN & Other & No & $\mathrm{F}$ \\
\hline 14 & {$[24]$} & $\mathrm{F}$ & 48 & BA, headache & 500 & No & CITRIN & $B+L T$ & No & $\mathrm{F}$ \\
\hline 15 & {$[23]$} & M & 38 & BA, headache, N, V & 434 & No & NAGS & PB & No & $\mathrm{F}$ \\
\hline 16 & {$[22]$} & M & 28 & Coma & 683 & Yes & CPS1 & $B+P B$ & No & $\mathrm{D}$ \\
\hline 17 & {$[21]$} & M & 49 & Coma & 254 & No & OTC & B & Yes & D \\
\hline 18 & {$[20]$} & $\mathrm{F}$ & 35 & BA, headache & 224 & No & CPS1 & $B+P B$ & No & $F$ \\
\hline 19 & [19] & M & 59 & Coma, S, N, V & 228 & No & OTC & B & Yes & $F$ \\
\hline 20 & [18] & $F$ & 23 & Headache, V & 477 & No & OTC & $B+P B$ & No & $F$ \\
\hline 21 & {$[17]$} & M & 47 & $S, V$ & 541 & Yes & OTC & - & Yes & $F$ \\
\hline 22 & {$[16]$} & M & 49 & $S, N$ & 157 & No & CPS1 & $B+L T$ & No & $\mathrm{F}$ \\
\hline 23 & {$[15]$} & M & 45 & S & 628 & Yes & OTC & - & No & D \\
\hline 24 & {$[14]$} & $\mathrm{F}$ & 31 & Other & 179 & No & OTC & PB & No & $F$ \\
\hline 25 & [13] & M & 17 & $\mathrm{~S}, \mathrm{~N}, \mathrm{~V}, \mathrm{Coma}$ & 787 & Yes & OTC & B & Yes & $\mathrm{D}$ \\
\hline 26 & {$[12]$} & M & 63 & S, coma & 1447 & Yes & OTC & $B+P B$ & Yes & $\mathrm{D}$ \\
\hline 27 & [11] & $F$ & 28 & Coma & 281 & No & OTC & $B+P B$ & Yes & $F$ \\
\hline 28 & {$[10]$} & $F$ & 60 & $\mathrm{~S}, \mathrm{BA}$, Coma, N, V & 256 & No & CPS1 & $B+P B$ & Yes & $\mathrm{D}$ \\
\hline 29 & {$[9]$} & $F$ & 25 & $\mathrm{~N}, \mathrm{~V}$ & 150 & No & CITRIN & PB & No & $\mathrm{F}$ \\
\hline 30 & [53] & M & 36 & BA & 696 & No & OTC & $B+P B$ & No & $\mathrm{F}$ \\
\hline 31 & {$[54]$} & $\mathrm{F}$ & 18 & $\mathrm{~S}, \mathrm{~N}, \mathrm{~V}$ & 23 & No & ARG & Other & No & $\mathrm{F}$ \\
\hline 32 & {$[55]$} & $\mathrm{F}$ & 40 & BA, Coma & 300 & No & CITRIN & Other & No & F \\
\hline 33 & {$[56]$} & M & 40 & BA, Coma & 390 & No & OTC & B & Yes & $\mathrm{F}$ \\
\hline 34 & [57] & $\mathrm{F}$ & 21 & Coma, N, V & 510 & No & OTC & B & No & $F$ \\
\hline 35 & {$[58]$} & M & 34 & BA, Coma & 2210 & Yes & CITRIN & Other & No & D \\
\hline 36 & [59] & $\mathrm{F}$ & 21 & S, BA, Coma & 698 & Yes & CITRIN & LT & No & $F$ \\
\hline 37 & {$[60]$} & M & 31 & $\mathrm{BA}$ & 396 & Yes & CITRIN & Other & No & D \\
\hline 38 & {$[61]$} & M & 31 & Other & 263 & No & CITRIN & LT & No & $\mathrm{F}$ \\
\hline 39 & {$[62]$} & M & 41 & BA & 483 & No & CITRIN & B & Yes & $F$ \\
\hline 40 & [63] & $F$ & 40 & $\mathrm{~S}, \mathrm{BA}$ & 234 & No & CIRTIN & Other & No & $F$ \\
\hline
\end{tabular}

M: male; F: female; S: seizure; N: nausea; V: vomiting, BA: behavioral abnormalities; ORNT1: ornithine transporter 1; OTC: ornithine transcarbamylase; NAGS: $\mathrm{N}$-Acetylglutamate synthase; ARG: arginase; CITRIN: aspartate/glutamate carrier; CPSI: Carbamyl phosphate synthetase 1; B: benzoate; PB: phenylbutyrate; LT: liver transplantation; D: died; F: favorable

\section{Clinical presentation}

A slower rise in ammonia increases brain levels of tryptophan, a precursor of serotonin. Increased serotonin production may contribute to behavioral abnormalities, migraine, headaches, and changes in cerebral blood flow
[2]. It is strongly recommended to consider an UCD at any age in the presence of an acute or intermittent neurological deterioration or a psychiatric pathology, an acute hepatic failure or intoxication. The trigger is a catabolic state or a high protein load [37]. 
Table 3 Frequency of different symptoms presented by patients

\begin{tabular}{lll}
\hline Symptoms & Frequency & $\%$ \\
\hline Confusion & 18 & 45 \\
Vomiting & 17 & 42 \\
Convulsions & 14 & 35 \\
Coma & 17 & 42 \\
Behavioral disorders & 14 & 35 \\
Nausea & 15 & 37 \\
Headaches & 6 & 15 \\
Loss of consciousness & 8 & 20 \\
\hline
\end{tabular}

Table 4 Frequency of factors favoring decompensation

\begin{tabular}{lcl}
\hline Circumstances & Patients $(\boldsymbol{n})$ & $\%$ \\
\hline Infection & 5 & 12 \\
Parenteral nutrition & 2 & 5 \\
Hyper-protein diet & 2 & 5 \\
Valproic acid & 2 & 5 \\
Post-partum & 2 & 5 \\
Post-operative & 1 & 2.5 \\
Myocardial infarction & 1 & 2.5 \\
Gastrointestinal bleeding & 1 & 2.5 \\
Unknown & 23 & 57 \\
\hline
\end{tabular}

Table 5 Different treatment type frequency

\begin{tabular}{lll}
\hline Treatment & Patients $(\boldsymbol{n})$ & $\%$ \\
\hline Low protein oral nutrition & 28 & 73 \\
Benzoate & 27 & 46 \\
L-Arginine & 21 & 50 \\
Dialysis & 14 & 34 \\
Phenylbutyrate & 10 & 19 \\
L-Carnitine & 7 & 27 \\
Citruline & 4 & 15 \\
Low protein parenteral nutrition & 7 & 15 \\
Hepatic transplantation & 4 & 7 \\
\hline
\end{tabular}

\section{Acute management in intensive care}

The treatment is clearly defined in the literature (Fig. 5) and can be started regardless of the type of enzyme deficiency underlying the urea cycle $[38,39]$, the goal of treatment being to reduce ammonia production and accelerate elimination via alternative pathways (Fig. 6).

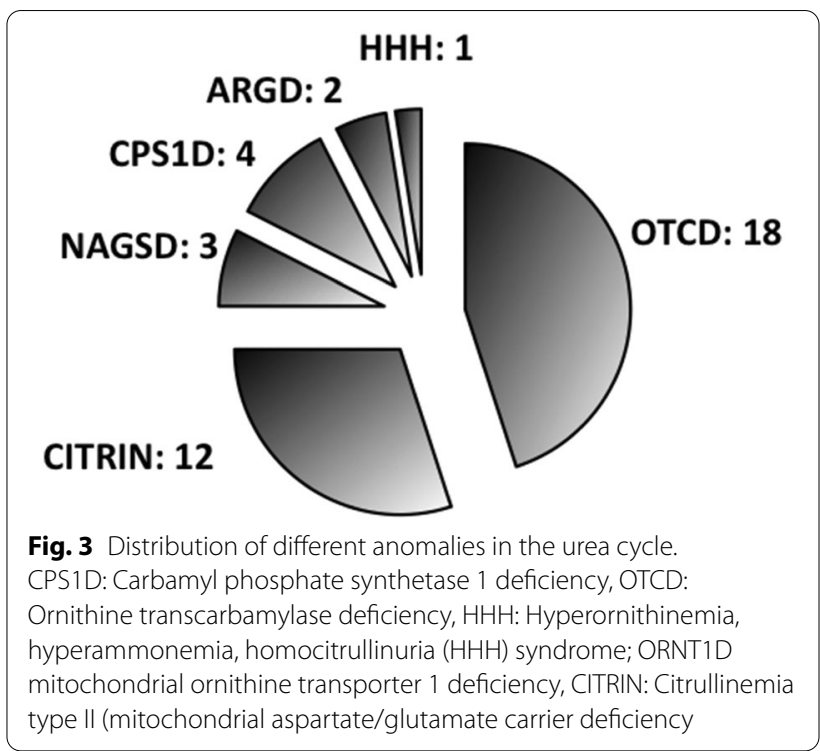

\section{Nutritional management}

Acute management of an enzyme deficiency in the urea cycle includes stopping any exogenous protein supply during $48 \mathrm{~h}$. Proteins must be re-introduced after $48 \mathrm{~h}$ to avoid endogenous protein catabolism. Energetic intake should be provided by infusion of dextrose $10-30 \%$ and a $20 \%$ fat emulsion $\left(\right.$ Intralipid $^{\circledR}$ ) to provide supranormal caloric intake to avoid catabolism with a transition as soon as possible to an oral diet with anti-emetics if necessary. The proteins are then reintroduced in a second time. Supplementation with L-Arginine or Citrulline is recommended to promote an alternative pathway of metabolism [5].

\section{L-arginine and L-carnitine}

Patients with defective urea synthesis could have a low arginine level which induces in these patients increased proteolysis as the degradation/synthesis cycle is interrupted. The administration of arginine in those patients limits proteolysis and thus promotes the reduction of urea [40]. L-Carnitine (LC) provides cerebral protection in case of hyperammonemia. LC crosses the blood brain barrier and causes alanine to drop by restoring mitochondrial respiration by improving pyruvate oxidation, Krebs cycling, and flux through glutamate dehydrogenase. It is via this effect on glutamate dehydrogenase that it is also explained a drop in the level of ammonia blood post administration of LC [41].

The administration of systematic arginine is subject to debate. In our review one patient out of 29 (3.4\%) had an arginase deficiency which lead to an increase in blood arginine level. Administering arginine under these 


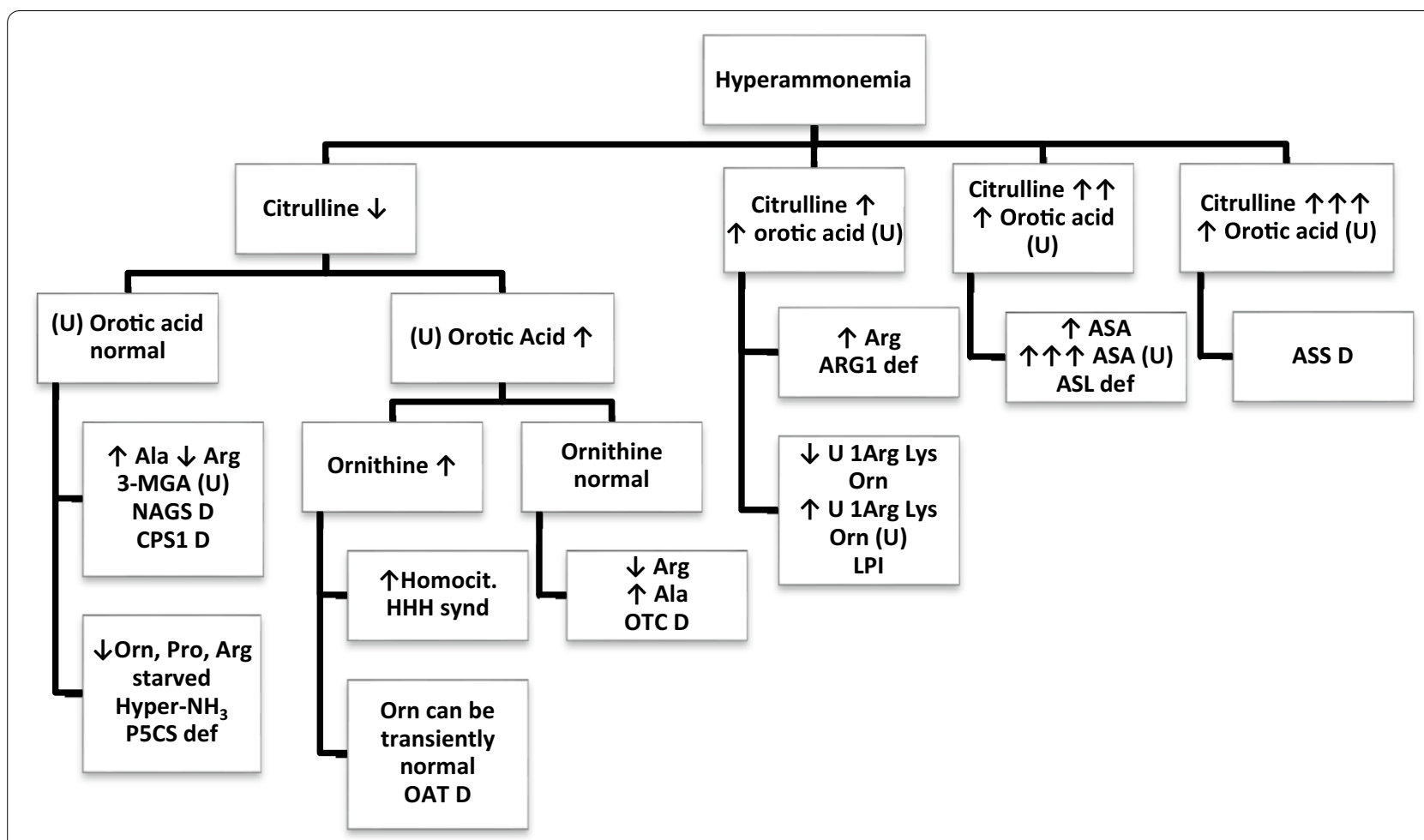

Fig. 4 diagnostic algorythm for late onset hyperammonemia. In case of hyperammonemia, the levels of citrulin and urinary orotic acid makes it possible to direct towards a specific analysis group leading to the final diagnosis. Unless indicated, with (U) to indicate urine. Ala: alanine, Arg: arginine, ARG1: arginase 1, 3-MGA: 3-methylglutaconic acid, NAGS: N-acetylglutamate synthase, CPS: carbamoylphosphate synthetase, Orn: ornithine, Pro: proline, P5CS: pyrroline-5-carboxyl synthetase, HHH: hyperornithinemia-hyperammonemia-homocitrullinuria, OAT: ornithine aminotransferase, OTC: ornithine transcarbamylase, Lys: Iysine, LPI: Iysinurix protein intolerance, ASA: arginosuccinic acid, ASS: arginosuccinate synthetase

conditions would increase the already high level of arginine. However, to our knowledge, there are no pathological repercussions of a high level of arginine.

\section{Scavenging agents}

Sodium benzoate, by the acetylation of glycine on hippuric acid, can extract one mole of nitrogen for each mole of benzoate administered. Sodium phenylacetate is conjugated with glutamine to form phenylacetylglutamine which is eliminated by the kidney (Fig. 6). Glutamine contains 2 nitrogen atoms, so each mole of sodium phenylacetate removes $2 \mathrm{~mol}$ of nitrogen. These conversions take place in the liver and kidney [42]. The main side effects of these drugs administered in IV are nausea, vomiting and hypokalemia [43]. Brusilow et al. reported the efficacy of sodium benzoate combined phenylacetate and arginine in patients with UCD in hyperammonemic crisis [40]. Enns et al. showed a 98\% survival rate in pediatric patients older than 30 days who presented with an hyperammonemic attack. This value reached $99 \%$ for children over 12 years old [44].

\section{$\mathrm{N}$-carbamoyl-L-glutamic acid}

$N$-Carbamoyl-L-glutamic acid (NCG or Carbaglu $\left.{ }^{\circledR}\right)$ is a structural analogue of $\mathrm{N}$-acetyl glutamate (NAG) that restores urea cycle function in inherited NAGS and CPS1 deficiency [45]. It works by replacing NAG which is an essential activator of CPS1 [46]. NCG has also shown its effectiveness in OTC deficiency. On one hand, since the activity of the OTC is decreased, it increases the pool of carbamyl phosphate available for this enzyme. On the other hand, it would increase the stability of the enzyme by promoting binding with carbamyl phosphate [47].

NCG is potentially useful in all other enzymatic deficiency urea cycle. It has been experimentally demonstrated that fasting and protein-free dieting, which are the cornerstones of UCD hyperammonemia management, lead to a decrease in NAG activity following a down-regulation mechanism and increased the activity of other downstream enzymes [48]. NCG is used to stimulate the residual activity of enzymes in the urea cycle. In addition, it acts as an activator of the urea cycle and has been proposed as a potential treatment for hyperammonemia secondary to organic acidemia, hepatic 


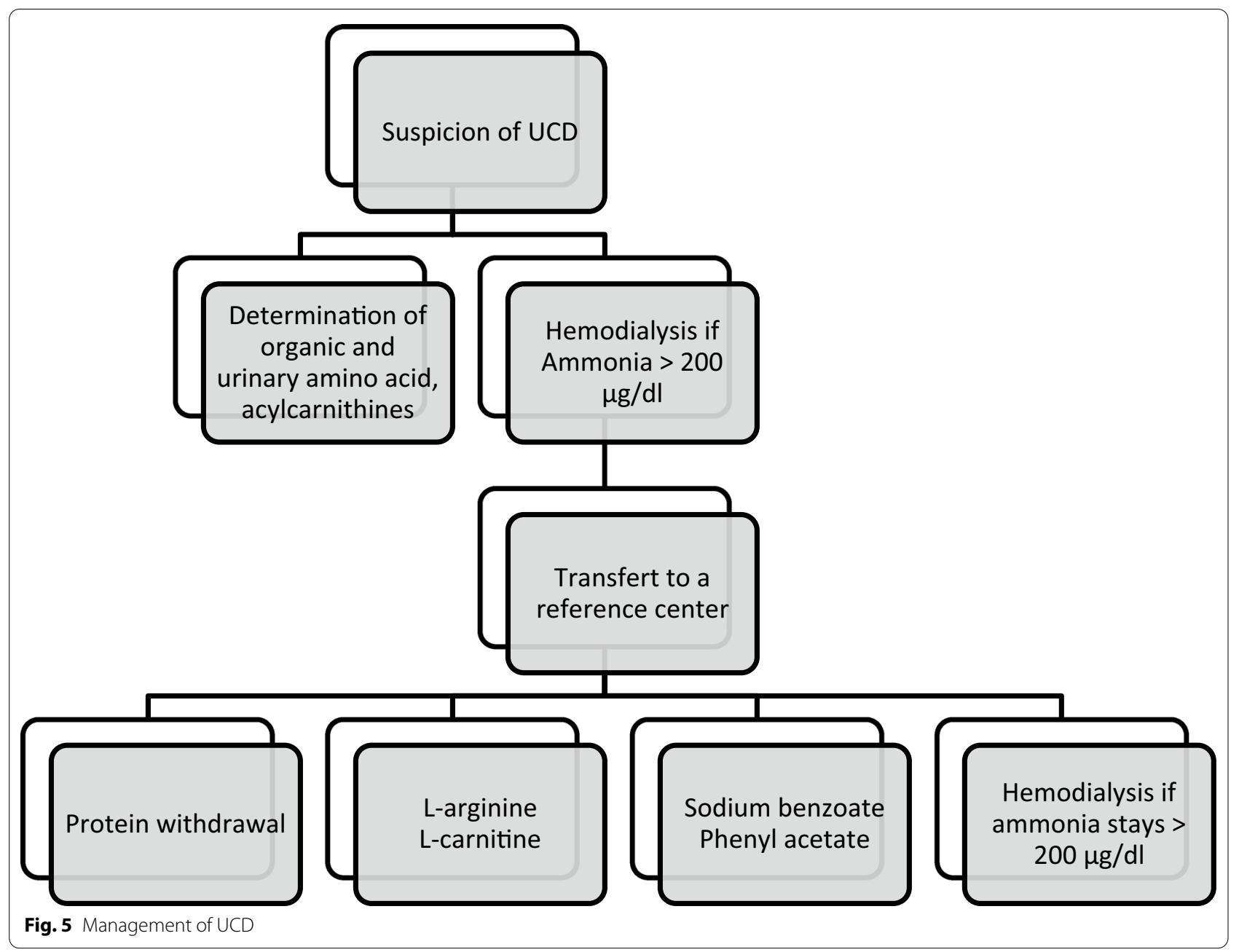

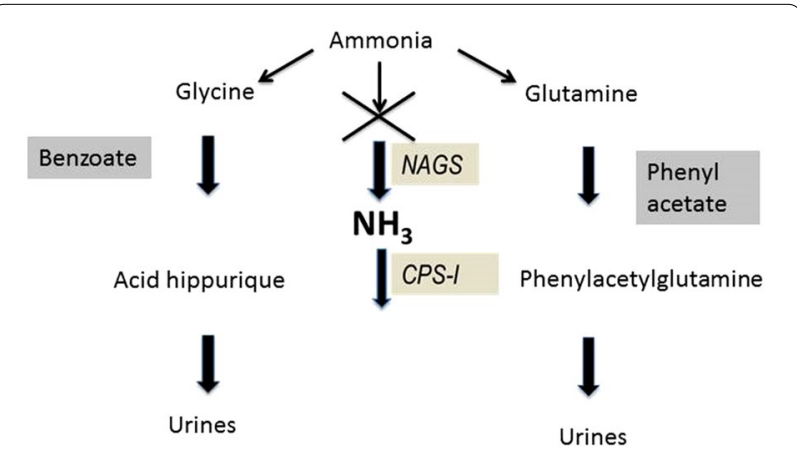

Fig. 6 Alternative pathways to reduce ammonia production and accelerate elimination. Ammonia is diverted to the glycine and hippuric acid pathway by benzoate, and to the glutamine and phenylacetylglutamine pathway allowing elimination in the urine without passing through the urea cycle encephalopathy and even valproic acid associated hyperammonemia $[46,47]$.

\section{Dialysis}

In 1979, Donn et al. showed the effectiveness of hemodialysis in the clearance of ammonia in a patient with OTC deficiency. The measured clearance was $12,600 \mu \mathrm{g} / \mathrm{h}$. This value was much higher than the value obtained by peritoneal dialysis or transfusion exchange [49]. Ammoncia has a clearance as important as urea and is therefore easily dialyzable.

Enns et al. reported that only $12 \%$ of hyperammonemia episodes were treated with renal replacement therapy. Most of them were treated with a combination of phenylacetate and benzoate treatment [44]. Batshaw et al. suggested in a review of 20 years of use of alternative pathway therapy that in hyperammonemia comas (ammonia $>250 \mu \mathrm{mol} / \mathrm{l}$ ), benzoate is insufficient even when combined with phenylacetate. Dialysis should be considered while maintaining benzoate as both therapies 
could potentially be synergistic [42]. The current recommendations are to consider hemodialysis in adults from a cut-off at $200 \mu \mathrm{g} / \mathrm{dl}$. Hemodialysis is the first-choice treatment because it is available everywhere and must be started before being transferred to a center specialized in metabolic pathologies where other medical treatments are available [37]. Given the rebound effect, it is advisable to continue with a continuous veno-venous hemodialysis (CVVHD). Some authors argue to replace HD with highflow CVVHD followed by conventional dose CVVHD when the ammonia is less than $150 \mu \mathrm{mol} / \mathrm{l}$ [50].

\section{Liver transplantation}

Liver transplantation is the definitive cure for urea cycle abnormalities. Transplantation is considered only in patients with recurrent hyperammonemia or resistant to medical treatment [51]. Moriorka et al. reported 51 cases of patients with urea cycle disorder who beneficiated from liver transplantation with a good result and a good quality of life. The need of dietary restriction and scavenging agents were totally eliminated after transplantation [52].

\section{Chronic management outside the intensive care}

Chronic treatment is initiated and followed by the specialists in metabolic disease. It consists of a strict diet, supplementation with L-Arginine and $\mathrm{L}$-carnitine and possibly a scavenging therapy adapted to the case [37].

\section{Conclusion}

Hyperammonemia associated with a urea cycle abnormality is a therapeutic emergency to prevent brain herniation and death. Having a high suspicion is important. The current recommendations are to consider hemodialysis in adults from a cut-off at $200 \mu \mathrm{g} / \mathrm{dl}$. Hemodialysis is the first-choice treatment before transferring the patient to a tertiary reference center where specific treatment options are available. The final diagnosis can be made after resolution of the hyperammonemia crisis and needs a close collaboration with the metabolic disorder specialist.

\begin{abstract}
Abbreviations
UCD: Urea cycle disorders; OTCD: Ornithine transcarbamylase deficiency; LC: L-carnitine; NCG: N-Carbamoyl-L-glutamic acid; OTC: Ornithine transcarbamylase; ARG: Arginase; NAGS: N-Acetylglutamate synthase; ASS: Argininosuccinate synthetaseS); CPS1: Carbamyl phosphate synthetase 1; ASL: Argininosuccinate lyase; ORNT1: Mitochondrial ornithine transporter 1; CITRIN: Mitochondrial aspartate/glutamate carrier.
\end{abstract}

\section{Acknowledgements}

We thank Melissa Jackson, M.D. for her English editing of the manuscript

\section{Authors' contributions}

$\mathrm{SR}, \mathrm{AE}, \mathrm{DDB}$ and PMH designed the paper. All authors participated in drafting and reviewing. All authors read and approved the final manuscript.
Funding

None.

Availability of data and materials

Not applicable.

Ethics approval and consent to participate

Not applicable.

\section{Consent for publication}

Not applicable.

\section{Competing Interests}

The authors declare to have no competing interests.

\section{Author details}

${ }^{1}$ Department of Intensive Care, Université Libre de Bruxelles (ULB), CHU Brugmann-Brugmann University Hospital, 4, Place Arthur Van Gehuchten, 1020 Brussels, Belgium. ${ }^{2}$ Department of Metabolic Diseases, Hôpital universitaire des enfants reine Fabiola, Université Libre de Bruxelles (ULB), Brussels, Belgium. ${ }^{3}$ Department of Internal Medicine, Brugmann University Hospital, Université Libre de Bruxelles (ULB), Brussels, Belgium.

Received: 18 May 2020 Accepted: 26 December 2020

Published online: 06 January 2021

\section{References}

1. Crosbie DC, Sugumar H, Simpson MA, Walker SP, Dewey HM, Reade MC. Late-onset ornithine transcarbamylase deficiency: a potentially fatal yet treatable cause of coma. Crit Care Resusc. 2009;11(3):222-7.

2. Thakur V, Rupar CA, Ramsay DA, Singh R, Fraser DD. Fatal cerebral edema from late-onset ornithine transcarbamylase deficiency in a juvenile male patient receiving valproic acid. Pediatr Crit Care Med. 2006;7(3):273-6. https://doi.org/10.1097/01.PCC.0000216682.56067.23.

3. Waisbren SE, Gropman AL, Members of the Urea Cycle Disorders $C$ Batshaw ML. Improving long term outcomes in urea cycle disordersreport from the Urea Cycle Disorders Consortium. J Inherit Metab Dis. 2016;39(4):573-84. https://doi.org/10.1007/s10545-016-9942-0.

4. Summar ML, Koelker S, Freedenberg D, Le Mons C, Haberle J, Lee HS, Kirmse B, European R. The incidence of urea cycle disorders. Mol Genet Metab. 2013;110(1-2):179-80. https://doi.org/10.1016/j.ymgme .2013.07.008.

5. Singh RH, Rhead WJ, Smith W, Lee B, Sniderman King L, Summar M. Nutritional management of urea cycle disorders. Crit Care Clin. 2005;21(4 Suppl):S27-35. https://doi.org/10.1016/j.ccc.2005.08.003.

6. van de Logt AE, Kluijtmans LA, Huigen MC, Janssen MC. Hyperammonemia due to adult-onset $\mathrm{N}$-acetylglutamate synthase deficiency. JIMD Rep. 2017;31:95-9. https://doi.org/10.1007/8904_2016_565.

7. Bijvoet GP, van der Sijs-Bos CJ, Wielders JP, Groot OA. Fatal hyperammonaemia due to late-onset ornithine transcarbamylase deficiency. Neth J Med. 2016;74(1):36-9.

8. Wijdicks EF. Hepatic encephalopathy. N Engl J Med. 2016;375(17):166070. https://doi.org/10.1056/NEJMra1600561.

9. Salek J, Byrne J, Box T, Longo N, Sussman N. Recurrent liver failure in a 25-year-old female. Liver Transpl. 2010;16(9):1049-53. https://doi. org/10.1002/lt.22118.

10. Wells DL, Thomas JB, Sacks GS, Zouhary LA. Late-onset urea cycle disorder in adulthood unmasked by severe malnutrition. Nutrition. 2014;30(78):943-7. https://doi.org/10.1016/j.nut.2013.12.011.

11. Weiss N, Mochel F, Rudler M, Demeret S, Lebray P, Conti F, Galanaud D, Ottolenghi C, Bonnefont JP, Dommergues M, Bernuau J, Thabut D. Peak hyperammonemia and atypical acute liver failure: The eruption of an urea cycle disorder during hyperemesis gravidarum. J Hepatol. 2017. https:// doi.org/10.1016/j.jhep.2017.09.009.

12. Ramanathan M, Uppalapu S, Patel NM. Hiding in plain sight: a case of ornithine transcarbamylase deficiency unmasked post-liver transplantation. Am J Transplant. 2017;17(5):1405-8. https://doi.org/10.1111/ ajt.14174. 
13. Alameri M, Shakra M, Alsaadi T. Fatal coma in a young adult due to late-onset urea cycle deficiency presenting with a prolonged seizure: a case report. J Med Case Rep. 2015;9:267. https://doi.org/10.1186/s1325 6-015-0741-2

14. Celik O, Buyuktas D, Aydin A, Acbay O. Ornithine transcarbamylase deficiency diagnosed in pregnancy. Gynecol Endocrinol. 2011;27(12):1052-4. https://doi.org/10.3109/09513590.2011.569787.

15. Bezinover D, Douthitt L, McQuillan PM, Khan A, Dalal P, Stene J, Uemura T, Kadry Z, Janicki PK. Fatal hyperammonemia after renal transplant due to late-onset urea cycle deficiency: a case report. Transplant Proc. 2010;42(5):1982-5. https://doi.org/10.1016/j.transproceed.2010.03.142.

16. Bates TR, Lewis BD, Burnett JR, So K, Mitchell A, Delriviere L, Jeffrey GP. Late-onset carbamoyl phosphate synthetase 1 deficiency in an adult cured by liver transplantation. Liver Transpl. 2011;17(12):1481-4. https:// doi.org/10.1002/lt.22407.

17. Ben-Ari Z, Dalal A, Morry A, Pitlik S, Zinger P, Cohen J, Fattal I, GaliliMosberg R, Tessler D, Baruch RG, Nuoffer JM, Largiader CR, Mandel H. Adult-onset ornithine transcarbamylase (OTC) deficiency unmasked by the Atkins' diet. J Hepatol. 2010;52(2):292-5. https://doi.org/10.1016/j. jhep.2009.11.014.

18. Brajon D, Carassou P, Pruna L, Feillet F, Kaminsky P. Ornithine transcarbamylase deficiency in adult. Rev Med Interne. 2010;31(10):709-11. https:// doi.org/10.1016/j.revmed.2010.02.008.

19. Choi DE, Lee KW, Shin YT, Na KR. Hyperammonemia in a patient with late-onset ornithine carbamoyltransferase deficiency. J Korean Med Sci. 2012;27(5):556-9. https://doi.org/10.3346/jkms.2012.27.5.556.

20. Fassier T, Guffon N, Acquaviva C, D'Amato T, Durand DV, Domenech P. Misdiagnosed postpartum psychosis revealing a late-onset urea cycle disorder. Am J Psychiatry. 2011;168(6):576-80. https://doi.org/10.1176/ appi.ajp.2010.10071032.

21. Machado MC, Fonseca GM, Jukemura J. Late-onset ornithine carbamoyltransferase deficiency accompanying acute pancreatitis and hyperammonemia. Case Rep Med. 2013;2013:903546. https://doi. org/10.1155/2013/903546.

22. Pillai U, Kahlon R, Sondheimer J, Cadnapaphorncai P, Bhat Z. A rare case of hyperammonemia complication of high-protein parenteral nutrition. JPEN J Parenter Enteral Nutr. 2013;37(1):134-7. https://doi. org/10.1177/0148607112447815.

23. Cartagena A, Prasad AN, Rupar CA, Strong M, Tuchman M, Ah Mew N, Prasad C. Recurrent encephalopathy: NAGS (N-acetylglutamate synthase) deficiency in adults. Can J Neurol Sci. 2013;40(1):3-9. https://doi. org/10.1017/s0317167100012877.

24. Noto D, Takahashi K, Hamaguchi T, Inamura K, Nobata K, Yazaki M, Ikeda S, Kobayashi K, Yamada M. A case of adult onset type II citrullinemia with portal-systemic shunt. J Neurol Sci. 2009;281(1-2):127-9. https://doi. org/10.1016/j.jns.2009.02.003.

25. Sakamoto S, Shinno H, Ikeda M, Miyoshi H, Nakamura Y. A patient with type II citrullinemia who developed refractory complex seizure. Gen Hosp Psychiatry. 2013;35(1):103. https://doi.org/10.1016/j.genhosppsy ch.2012.03.019.

26. Yazaki M, Kinoshita M, Ogawa S, Fujimi S, Matsushima A, Hineno A, Tazawa K, Fukushima K, Kimura R, Yanagida M, Matsunaga H, Saheki T, Ikeda S. A 73-year-old patient with adult-onset type II citrullinemia successfully treated by sodium pyruvate and arginine. Clin Neurol Neurosurg. 2013;115(8):1542-5. https://doi.org/10.1016/j.clineuro.2012.12.027.

27. Takahashi Y, Koyama S, Tanaka H, Arawaka S, Wada M, Kawanami T, Haga H, Watanabe H, Toyota K, Numakura C, Hayasaka K, Kato T. An elderly Japanese patient with adult-onset type II citrullinemia with a novel D493G mutation in the SLC25A13 gene. Intern Med. 2012;51(16):2131-4. https://doi.org/10.2169/internalmedicine.51.7644.

28. Koya Y, Shibata M, Senju M, Honma Y, Hiura M, Ishii M, Matsumoto S, Harada M. Hyperammonemia in a woman with late-onset ornithine transcarbamylase deficiency. Intern Med. 2019;58(7):937-42. https://doi. org/10.2169/internalmedicine.1851-18.

29. Maramattom BV, Raja R, Balagopal A. Late onset arginase deficiency presenting with encephalopathy and midbrain hyperintensity. Ann Indian Acad Neurol. 2016;19(3):392-4. https://doi.org/10.4103/0972-2327.16770 1.

30. Upadhyay R, Bleck TP, BusI KM. Hyperammonemia: what urea-lly need to know: case report of severe noncirrhotic hyperammonemic encephalopathy and review of the literature. Case Rep Med. 2016;2016:8512721. https://doi.org/10.1155/2016/8512721.

31. Daijo K, Kawaoka T, Nakahara T, Nagaoki Y, Tsuge M, Hiramatsu A, Imamura M, Kawakami Y, Aikata H, Hara K, Tajima G, Kobayashi M, Chayama K. Late-onset ornithine transcarbamylase deficiency associated with hyperammonemia. Clin J Gastroenterol. 2017;10(4):383-7. https://doi. org/10.1007/s12328-017-0753-0.

32. Cavicchi C, Chilleri C, Fioravanti A, Ferri L, Ripandelli F, Costa C, Calabresi P, Prontera P, Pochiero F, Pasquini E, Funghini S, la Marca G, Donati MA, Morrone A. Late-onset $\mathrm{N}$-acetylglutamate synthase deficiency: report of a paradigmatic adult case presenting with headaches and review of the literature. Int J Mol Sci. 2018;19:2. https://doi.org/10.3390/ijms19020345.

33. Hershman M, Carmody R, Udayasankar UK. Case 252: acute hyperammonemic encephalopathy resulting from late-onset ornithine transcarbamylase deficiency. Radiology. 2018;287(1):353-9. https://doi.org/10.1148/ radiol.2018161834.

34. Silfverberg T, Sahlander F, Enlund M, Oscarson M, Hardstedt M. Late onset hyperornithinemia-hyperammonemia-homocitrullinuria syndrome - how web searching by the family solved unexplained unconsciousness: a case report. J Med Case Rep. 2018;12(1):274. https://doi.org/10.1186/s1325 6-018-1794-9.

35. Bernal W, Hall C, Karvellas CJ, Auzinger G, Sizer E, Wendon J. Arterial ammonia and clinical risk factors for encephalopathy and intracranial hypertension in acute liver failure. Hepatology. 2007;46(6):1844-52. https ://doi.org/10.1002/hep.21838.

36. Cordoba J, Blei AT, Mujais S. Determinants of ammonia clearance by hemodialysis. Artif Organs. 1996;20(7):800-3.

37. Haberle J, Burlina A, Chakrapani A, Dixon M, Karall D, Lindner M, Mandel H, Martinelli D, Pintos-Morell G, Santer R, Skouma A, Servais A, Tal G, Rubio V, Huemer M, Dionisi-Vici C. Suggested guidelines for the diagnosis and management of urea cycle disorders: First revision. J Inherit Metab Dis. 2019;42(6):1192-230. https://doi.org/10.1002/jimd.12100.

38. Brusilow SW, Maestri NE. Urea cycle disorders: diagnosis, pathophysiology, and therapy. Adv Pediatr. 1996;43:127-70.

39. Kleppe S, Mian A, Lee B. Urea Cycle Disorders. Curr Treat Options Neurol. 2003;5(4):309-19.

40. Brusilow SW. Arginine, an indispensable amino acid for patients with inborn errors of urea synthesis. J Clin Invest. 1984;74(6):2144-8. https:// doi.org/10.1172/JCl111640.

41. Malaguarnera M, Pistone G, Astuto M, Dell'Arte S, Finocchiaro G, Lo Giudice E, Pennisi G. L-Carnitine in the treatment of mild or moderate hepatic encephalopathy. Dig Dis. 2003;21(3):271-5. https://doi. org/10.1159/000073347.

42. Batshaw ML, MacArthur RB, Tuchman M. Alternative pathway therapy for urea cycle disorders: twenty years later. J Pediatr. 2001;138(1 Suppl):S46-54.

43. Clay AS, Hainline BE. Hyperammonemia in the ICU. Chest. 2007;132(4):1368-78. https://doi.org/10.1378/chest.06-2940.

44. Enns GM, Berry SA, Berry GT, Rhead WJ, Brusilow SW, Hamosh A. Survival after treatment with phenylacetate and benzoate for urea-cycle disorders. N Engl J Med. 2007;356(22):2282-92. https://doi.org/10.1056/NEJMo a066596.

45. Caldovic L, Morizono H, Daikhin Y, Nissim I, McCarter RJ, Yudkoff M, Tuchman M. Restoration of ureagenesis in N-acetylglutamate synthase deficiency by N-carbamylglutamate. J Pediatr. 2004;145(4):552-4. https:// doi.org/10.1016/j.jpeds.2004.06.047.

46. Chapel-Crespo CC, Diaz GA, Oishi K. Efficacy of N-carbamoyl-L-glutamic acid for the treatment of inherited metabolic disorders. Expert Rev Endocrinol Metab. 2016;11(6):467-73. https://doi.org/10.1080/17446 651.2016.1239526.

47. Ah Mew N, Payan I, Daikhin Y, Nissim I, Nissim I, Tuchman M, Yudkoff M. Effects of a single dose of $\mathrm{N}$-carbamylglutamate on the rate of ureagenesis. Mol Genet Metab. 2009;98(4):325-30. https://doi.org/10.1016/j. ymgme.2009.07.010.

48. Schimke RT. Differential effects of fasting and protein-free diets on levels of urea cycle enzymes in rat liver. J Biol Chem. 1962;237:1921-4.

49. Donn SM, Swartz RD, Thoene JG. Comparison of exchange transfusion, peritoneal dialysis, and hemodialysis for the treatment of hyperammonemia in an anuric newborn infant. J Pediatr. 1979;95(1):67-70.

50. Redant S, Beretta-Piccoli X, Mugisha A, Attou R, Kaefer K, De Bels D, Tolwani A, Honore PM. Hyperammonemia, the last indication of 
high-volume hemodiafiltration in adult and children: a structured review. Blood Purif. 2019;48(4):330-5. https://doi.org/10.1159/000501390.

51. Machado MC, Pinheiro da Silva F. Hyperammonemia due to urea cycle disorders: a potentially fatal condition in the intensive care setting. J Intensive Care. 2014;2(1):22. https://doi.org/10.1186/2052-0492-2-22.

52. Morioka D, Kasahara M, Takada Y, Shirouzu Y, Taira K, Sakamoto S, Uryuhara K, Egawa H, Shimada H, Tanaka K. Current role of liver transplantation for the treatment of urea cycle disorders: a review of the worldwide English literature and 13 cases at Kyoto University. Liver Transpl. 2005;1 1(11):1332-42. https://doi.org/10.1002/lt.20587.

53. Atiq M, Holt AF, Safdar K, Weber F, Ravinuthala R, Jonas ME, Neff GW Adult onset urea cycle disorder in a patient with presumed hepatic encephalopathy. J Clin Gastroenterol. 2008;42(2):213-4. https://doi. org/10.1097/01.mcg.0000225628.84168.25.

54. Cowley DM, Bowling FG, McGill JJ, van Dongen J, Morris D. Adult-onset arginase deficiency. J Inherit Metab Dis. 1998;21 (6):677-8. https://doi. org/10.1023/a:1005492819527.

55. Hagiwara N, Sekijima Y, Takei Y, Ikeda S, Kawasaki S, Kobayashi K, Saheki T. Hepatocellular carcinoma in a case of adult-onset type II citrullinemia. Intern Med. 2003;42(10):978-82. https://doi.org/10.2169/internalmedicin e.42.978.

56. Panlaqui OM, Tran K, Johns A, McGill J, White H. Acute hyperammonemic encephalopathy in adult onset ornithine transcarbamylase deficiency. Intensive Care Med. 2008;34(10):1922-4. https://doi.org/10.1007/s0013 4-008-1217-2.

57. Rimbaux S, Hommet C, Perrier D, Cottier JP, Legras A, Labarthe F, Lemarcis L, Autret A, Maillot F. Adult onset ornithine transcarbamylase deficiency: an unusual cause of semantic disorders. J Neurol Neurosurg Psychiatry. 2004;75(7):1073-5. https://doi.org/10.1136/jnnp.2003.026542.

58. Takagi H, Hagiwara S, Hashizume H, Kanda D, Sato K, Sohara N, Kakizaki S, Takahashi H, Mori M, Kaneko H, Ohwada S, Ushikai M, Kobayashi K,
Saheki T. Adult onset type II citrullinemia as a cause of non-alcoholic steatohepatitis. J Hepatol. 2006:44(1):236-9. https://doi.org/10.1016/j. jhep.2005.08.024.

59. Takashima Y, Koide M, Fukunaga H, Iwai M, Miura M, Yoneda R, Fukuda T, Kobayashi K, Saheki T. Recovery from marked altered consciousness in a patient with adult-onset type II citrullinemia diagnosed by DNA analysis and treated with a living related partial liver transplantation. Intern Med. 2002;41(7):555-60. https://doi.org/10.2169/internalmedicine.41.555.

60. Tazawa K, Shimojima Y, Okano T, Yazaki M, Takei Y, Shimojo H, Kobayashi K, Saheki T, Ikeda S. An autopsy case with adult onset type II citrullinemia showing myelopathy. J Neurol Sci. 2007;253(1-2):77-80. https://doi. org/10.1016/j.jns.2006.11.014.

61. Terada R, Yamamoto K, Kobayashi K, Sakaguchi K, Iwasaki Y, Saheki T, Shiratori Y. Adult-onset type II citrullinemia associated with idopathic hypertriglyceridemia as a preceding feature. J Gastroenterol Hepatol. 2006;21(10):1634-5. https://doi.org/10.1111/j.1440-1746.2006.04339.x.

62. Tsai CW, Yang CC, Chen HL, Hwu WL, Wu MZ, Liu KL, Wu MS. Homozygous SLC25A13 mutation in a Taiwanese patient with adult-onset citrullinemia complicated with steatosis and hepatocellular carcinoma. J Formos Med Assoc. 2006;105(10):852-6. https://doi.org/10.1016/S0929-6646(09)60274 $-6$.

63. Kyo M, Mii H, Takekita Y, Tokuhara D, Yazaki M, Nakamori Y, Kono S, Kinoshita T. Case of adult-onset type II citrullinemia treated as schizophrenia for a long time. Psychiatry Clin Neurosci. 2015;69(5):306-7. https://doi. org/10.1111/pcn.12253.

\section{Publisher's Note}

Springer Nature remains neutral with regard to jurisdictional claims in published maps and institutional affiliations.

\section{Submit your manuscript to a SpringerOpen ${ }^{\circ}$ journal and benefit from:}

- Convenient online submission

- Rigorous peer review

- Open access: articles freely available online

- High visibility within the field

- Retaining the copyright to your article

Submit your next manuscript at $\boldsymbol{\nabla}$ springeropen.com 